\title{
Associations of prenatally detected choroid plexus cysts with biochemical risk for congenital disorders
}

\section{Związek torbieli splotu naczyniówkowego stwierdzonych w badaniach prenatalnych i ryzyka biochemicznego wystapienia wad wrodzonych}

\author{
Danielius Serapinas, Marius Sukys, Povilas Bardziliauskas \\ Department of Pulmonology and Immunology, Lithuanian University of Health Sciences, Mykolas Romeris University Kaunas, Lithuania, \\ Head of Department: Prof. Raimundas Sakalauskas MD, PhD
}

Key words: choroid plexus cyst, trisomy 21, trisomy 18 , neural tube defect.

Słowa kluczowe: torbiel splotu naczyniówkowego, trisomia 21, trisomia 18, wada cewy nerwowej.

\begin{abstract}
Introduction: Choroid plexus cysts are one of the foetus ultrasonography findings that raise parents' concerns about their child's health. Usually cysts are found in an estimated $1 \%$ all performed ultrasonographies.

Aim of the research: To evaluate the risk of Down syndrome, Edward's syndrome and neural tube defect when choroid plexus cysts are found.

Material and methods: The risks of Down syndrome, Edward's syndrome and neural tube defect were calculated by using second-trimester biomarkers ( $\alpha$-fetoprotein, human choriongonadotropin, unconjugated estriol) for patients with choroid plexus cysts. A control group was selected randomly with calculated risks and without any abnormal ultrasonography findings. These risks were compared between the two groups.

Results: Twelve pregnancies with diagnosed choroid plexus cysts were included in this study during the year 2012. Choroid plexus cyst findings during this case/control study have shown that only one case from the test group had progressed to more serious foetal aberrations (Edward's syndrome); nonetheless, this progression did not influence statistically significant changes in the test and control groups. No statistically significant changes between the risks of disorders according the PRISCA method were observed in the appearance of Down syndrome or neural tube defect.

Conclusions: There is no data that choroid plexus cysts increase the risk of Down syndrome, Edward's syndrome and neural tube defect.
\end{abstract}

\section{Streszczenie}

Wprowadzenie: Stwierdzenie torbieli splotu naczyniówkowego to jeden z wyników badania ultrasonograficznego płodu, który wywołuje u rodziców zaniepokojenie co do stanu zdrowia ich dziecka. Szacuje się, że torbiele występują zazwyczaj w $1 \%$ wszystkich wykonanych badań ultrasonograficznych.

Cel pracy: Ocena ryzyka wystąpienia zespołu Downa, zespołu Edwardsa i wady cewy nerwowej w przypadku obecności torbieli splotu naczyniówkowego.

Materiał i metody: Ryzyko wystąpienia zespołu Downa, zespołu Edwardsa i wady cewy nerwowej określono przy zastosowaniu markerów drugiego trymestru ciąży (a-fetoproteiny, gonadotropiny kosmówkowej, wolnego estriolu) u pacjentów, u których stwierdzono torbiele splotu naczyniówkowego. Grupę kontrolną stanowiła wybrana losowo grupa osób, u których występuje określone ryzyko, lecz nie stwierdzono nieprawidłowości w badaniu ultrasonograficznym. Obie grupy porównano pod względem powyższego ryzyka.

Wyniki: Badaniem objęto 12 ciąż ze stwierdzonymi torbielami splotu naczyniówkowego w 2012 r. Tylko w jednym przypadku z grupy badanej rozwinęły się poważne wady płodu (zespół Edwardsa); niemniej jednak nie miało to wpływu na istotne statystycznie zmiany w grupie badanej i kontrolnej. Nie zaobserwowano istotnych statystycznie różnic między ryzykiem wystąpienia zaburzeń określonym metodą PRISCA dla zespołu Downa lub wady cewy nerwowej.

Wnioski: Nie istnieją dane wskazujące, że torbiele splotu naczyniówkowego powodują zwiększenie ryzyka wystąpienia zespołu Downa, zespołu Edwardsa czy wady cewy nerwowej. 


\section{Introduction}

Choroid plexus cysts (CPC) are cerebrospinal fluid-filled areas of variable size, within the substance of the choroid plexus [1]. Choroid plexus cysts, single or multiple, unilateral or bilateral, may be a normal variant, but often indicate increased risk of aneuploidy, especially if any other abnormalities are noted. They are often an indication for foetal karyotype analysis [2].

The cysts are generally located in the atrium of the lateral ventricles, are detected between 16 and 21 weeks of gestation, and range in size from $3 \mathrm{~mm}$ to $20 \mathrm{~mm}$ in diameter (mostly $<10 \mathrm{~mm}$ ). The cyst is lined by simple cuboidal or columnar epithelium and connected to, or contained within, the choroid plexus. They are most often found in the posterior lateral ventricles [3]. The overwhelming majority disappear by 23-24 weeks gestation [3]. Ultrasonographic evaluation of the choroid plexus, using an axial view through the upper portion of the foetal head, can frequently reveal the presence of one or more discrete cysts [4]. In recent years, improved ultrasound equipment has greatly increased the successful finding rate from $1 / 300$ to $1 / 90$ in second-trimester ultrasound tests [3].

A papilloma of the choroid is distinguishable because it is a solid tumour with marked echogenicity. Rarely, a CPC may occur in the body of the lateral ventricle and may simulate hydrocephalus. It should be distinguished by its echogenic wall and course over time [3]. It remains problematic as to whether this type of cyst is a true malformation or simply a variation in normal development [3].

Because diagnosing a CPC mid-gestation is a common finding, and various studies suggest that it may have an effect on the formation and development on the foetus, it is important to assess the extent of CPC and its effect on the foetus. Previous studies have shown that the prevalence of foetal CPC was 2347 cases in 286,441 subjects $(0.82 \%)$ with a range of $0.18 \%$ to $3.64 \%$ (Peleg and Yankowitz reviewed 33 series published up to 1997) [3]. We tried to look for CPC association with chromosomal aberrations (Down syndrome, Edward's syndrome) and neural tube defect (NTD) using PRISCA software.

\section{Aim of the research}

The aim of the study was to evaluate the risk of Down's syndrome, Edward's syndrome and NTD in pregnancies with detected fetal choroid plexus cysts.

\section{Material and methods}

In this retrospective study to test our thesis, that CPC may have a significant effect on chromosomal aberrations and neural tube defects, we collected and analysed data of pregnant women who were consulted by a genetic specialist at the Lithuanian Health Sci- ence University Kaunas Clinic from $20121^{\text {st }}$ of February to $20131^{\text {st }}$ of March and who had CPC ultrasound findings during second-trimester routine echoscopy. Of all the suitable cases, those with prescribed second-trimester biochemical marker tests for genetic disorders were selected. The tests were intended to observe Down syndrome, Edward's syndrome and neural tube defect. The tests used the markers $\alpha$-fetoprotein, human choriongonadotropin and unconjugatedestriol, which were studied from blood samples. After obtaining the marker concentration levels in the blood, the results were converted into a risk for disorders using PRISCA software (prenatal risk calculation). To correctly calculate the risk of disorder, the program needs the date of birth of the pregnant woman, her weight, smoking habits and additional diseases. Such options as twins, in vitro fertilization and time of gestation are also taken into account. If the program displayed an increased risk for a disorder, additional tests were recommended to identify the karyotype of the foetus. Furthermore, repeated ultrasound tests should be performed for all women after 2 weeks from the latest echoscopy, to monitor the status of the CPC. The control group was selected randomly using two criteria: second-trimester biochemical marker tests had been performed and there were no CPC findings during foetal ultrasound. Calculated risk of disorders using the PRISCA method were compared between the case/control groups using SPSS 20.0 with Mann-Whitney test. Every person who entered the study signed a consent form for their medical data to be used for medical studies, with an assurance of anonymity.

\section{Results}

In the test group of $\mathrm{CPC}$, which consisted of $12 \mathrm{sub}$ jects, there were unilateral and bilateral cysts, th epositions and number of which considerably varied from subject to subject during the second-trimester ultrasound testing. During a repeated ultrasound examination in the later period of the gestation, 11 out of 12 cases with CPC had disappeared, leaving only one case, which had also developed an intraventricular septum defect. This case was confirmed as Edward's syndrome after performing a karyotype analysis.

In all other cases there was no additional pathological data. The foetus echoscopy was done, on average, on day $132 \pm 6$ of pregnancy in the test group, and in the control group on day $130 \pm 10$. In the control group there were no confirmed disorders. Average maternal age in the test group was 37.75 years, and in the control group - 35.25 years. The average calculated risks in the test group were: Edward's syndrome 1 in $31502.82 \pm 12164$; Downs's syndrome 1 in 2004 \pm 741 ; NTD 1 in $33646 \pm 13066$ and in control group risks were: 1 in $1316 \pm 6931$; 1 in $986.27 \pm 332$; 1 in $16936 \pm 6317$ respectively. 

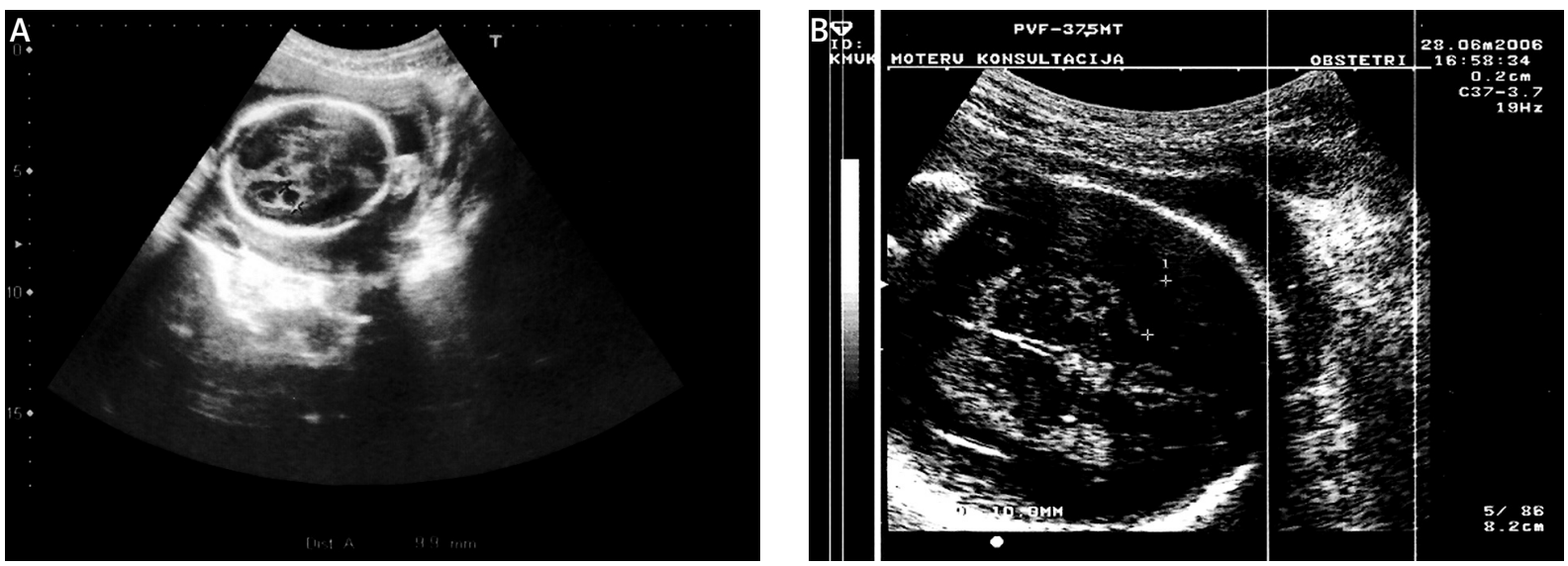

Figure 1. Prenatally detected choroid plexus cyst (A) and the same patient after 4 weeks (B). The CPC have disappeared

\section{Statistical analysis}

We compared the counted risks between the groups using the Mann-Whitney test, which showed no statistically significant difference at the significance level of $95 \%$.

\section{Discussion}

Choroid plexus cysts may be a valuable source of information in determining the formation of Edward's syndrome and other disorders. Women who are pregnant at an older age have increased risk of a variety of foetal malformations and chromosomal aberrations. These women tend to stress more about their pregnancies; knowing the higher risk of malformations and finding out about CPC, women often believe that their child might have some serious genetic disorder, which may even affect its life. Consequently, it is important to clarify to patients whether this condition can effect foetus development and health. One of the tools to evaluate risk of disorders may be triple-marker screening with PRISCA.

The PRISCA method used to determine the increased risk of disorder for chromosomal aberrations and neural tube defect, also used in the study, allows not only assessment of the risk level and possibility of birth defects, but also an objective comparison of these possibilities with other diseases. There are other studies that have tried to evaluate the relationship between CPC and Edward's syndrome, but still very few have attempted to assess the connection with Down syndrome or NTD.

Our research results show that there are no statistically significant differences between test and control groups for the risk level of disease. However, in the test group there was 1 case of 18 trisomy, proven by FISH; in the control group there were no proven diseases, but a low number of cases. These results were received using second-trimester biochemical markers with a 70\% significance level.

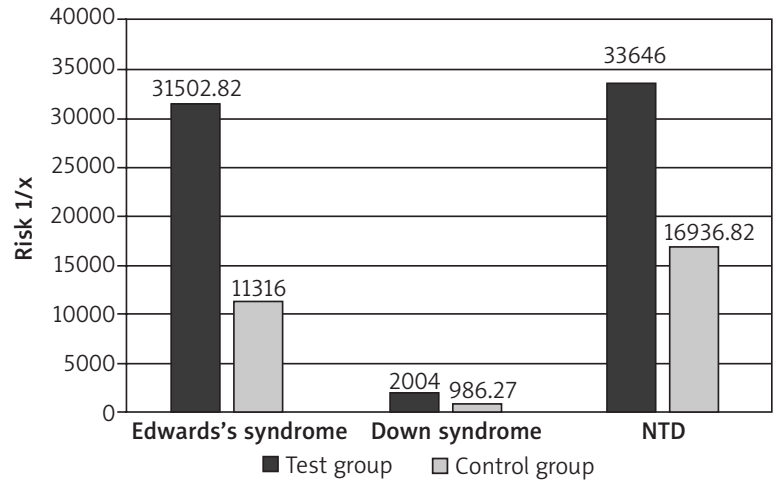

Figure 2. This diagram shows the calculated PRISCA average risks within groups. The number shows the probability of a disease by 1 from $N$ cohort of referent patients. In the test group, the risks are lower

Our results support the theory that there is no higher risk of chromosomal abnormalities or NTD, if CPC is found. To confirm our results, we searched for similar studies. One study analysed 263 isolated $\mathrm{CPC}$ to find an association with 18 trisomy and other abnormalities. They concluded that if there were no additional risks factors (advanced maternal age, additional ultrasonographic abnormalities, past obstetric history, or family history), there is no association with 18 trisomy [5].

Another study analysed 102 cases of CPC, and found that 7 had 18 trisomy (Edward's syndrome). What is important in this study is that the researchers were looking for additional foetal anomalies supporting Edward's syndrome, and only in one case were there no additional anomalies [6]. Without additional ultrasonographic abnormal findings, the risk of trisomy 18 is lower.

This study concluded that ultrasonography and triple-screen testing for foetuses with CPC (serum $\alpha$-fetoprotein, human chorionic gonadotropin and estriol) are enough to exclude chromosomal abnor- 
malities, and amniocentesis is not indicated [7]. Previous studies have shown that CPC observed during the second trimester of pregnancy tend to disappear in the later weeks of gestation, and have no impact on the formation of the foetus [8]. Some earlier reports have suggested a possible relationship between CPC and trisomy 21. Bromley et al. did not find such an association [9].

These studies suggest that if CPC is found, further analysis should be performed to clarify if there are no additional risk factors. Repeated echoscopy and second-trimester biochemical markers should be performed to exclude 18 trisomy or other chromosomal abnormalities. If there are more abnormal findings in the ultrasound or CPC has not disappeared in the repeated echoscopy, or if there is an increased risk shown by PRISCA, then invasive tests (foetal amniotic fluid cell FISH analysis or karyotyping) should be performed. Also, there is a non-invasive test that uses cellfree foetal DNA found in maternal circulation [10].

\section{Conclusions}

Choroid plexus cyst findings during this case/control study have shown that only 1 case from the test group had progressed to more serious foetal aberrations (Edward's syndrome); nonetheless, this progression did not influence statistically significant changes in the test and control groups. No statistically significant changes between the risks of disorders according the PRISCA method were observed in the appearance of Down syndrome or neural tube defect.

\section{Acknowledgments}

This study was financially supported by the Lithuanian University of Health Sciences.

\section{References}

1. Cameron A. Fetal Medicine for the MRCOG and Beyond. 2011; 55.

2. Gilbert-Barness E. Embryo and fetal pathology: color atlas with ultrasound correlation. University Press, Cambridge 2004; 122 .

3. Stevenson R, Hall J. Human malformations and related anomalies. Association of American Publishers 2006; 698700 .

4. Queenan JT, Hobbins JC, Spong YC. Protocols for highrisk pregnancies. Wiley-Blackwell 2010; 680.

5. Reinsch RC. Choroid plexus cysts - association with trisomy: prospective review of 16,059 patients. Am J Obstet Gynecol 1997; 176: 1381-3.

6. Sahinoglu Z, Uludogan M, Sayar C, et al. Second trimester choroid plexus cysts and trisomy 18. Int J Gynecol Obstet 2004; 85: 24-9.

7. Sullivan A, Giudice T, Vavelidis F, Thiagarajah S. Choroid plexus cysts: is biochemical testing a valuable adjunct to targeted ultrasonography? Am J Obstet Gynecol 1999; 181: $260-5$.
8. Fong K, Chong K, Toi A, et al. Fetal ventriculomegaly secondary to isolated large choroid plexus cysts: prenatal findings and postnatal outcome. Prenat Diagn 2011; 31: 395-400.

9. Bromley B, Lieberman E, Benacerraf B. Choroid plexus cysts: not associated with Down syndrome. Ultrasound Obstet Gynecol 1996; 8: 232-5.

10. Skirton H, Goldsmith L, Jackson L, et al. Offering prenatal diagnostic tests: European guidelines for clinical practice guidelines. Eur J Hum Genet 2013; 22: 1-7.

\section{Address for correspondence:}

Danielius Serapinas MD, PhD

Department of Pulmonology and Immunology

Medical Academy

Lithuanian University of Health Sciences

Eiveniu 2, LT 50009 Kaunas, Lithuania

Phone: $+37061490479,+37037326771$

Fax: +37037326953

E-mail: dserapinas@gmail.com 